\title{
ANALYSIS OF THE INFLUENCE OF FINANCING ON THE VALUE OF SHARIA BANKS WITH PROFITABILITY AS INTERVENING VARIABLES
}

\author{
Imam Azizuddin \\ Universitas Islam Negeri Malang \\ imamazaizuddin@uin-malang.ac.id
}

\begin{abstract}
This study aims to analyze the influence of NUC and NCC financing on Sharia commercial banks' value using variable profitability as variable intervening.

The data used in exploring the impact of this financing is obtained from the financial statements issued by OJK with data from 2016-2019. The data analysis used in this study uses path analysis.

This study shows that nuc has a significant effect on profitability but has no significant impact on the value of sharia banks. In contrast to the NCC results that have absolutely no significant impact on Sharia banks' profitability and value. This study also provides information that nuc has no effect on the importance of sharia banks with profitability as variable intervening, in contrast to NCC, which affects the value of sharia banks with profitability as variable intervening.
\end{abstract}

Keywords: NUC, NCC, Profitability, Sharia bank value

\section{INTRODUCTION}

Sharia banks, as financial institutions, seek to carry out business transaction interactions that apply sharia policy to eliminate the practice of unilateral profit in the transaction of its products, commonly referred to as interest that leads to usury. Based on MUI fatwa No.1 year 2004, interest is an excess imposed on loan transactions obtained from the principal count of the loan regardless of the principal's use based on the agreed time. The calculation is delivered at the beginning of the agreement and based on the percentage. Such excess practice is haraam either by financial institutions, either banks or non-banks and other financial institutions or carried out by individuals (Majelis Ulama Indonesia, 2004).

Islamic financial institutions' growth in the form of banks is experiencing very fast, interesting to review because Sharia banking is a new industry in Indonesia. This can be seen from the role of the community in using sharia banking products, one of which is financing 
distribution products (Rivai, 2017). Financing is funding provided by a party to another party to support the planned investment, either done alone or institutionally. In other words, financing is funding spent to support planned investments (Muhammad Lathief Ilhamy Nasution, 2018).

Indonesia's sharia-compliant economic financing instruments continue to increase (Chart 1.1), although further acceleration is needed to boost growth. When viewed from the share of financing in accordance with sharia principles, it can be indicated that there is still a wide gap between the needs of Sharia businesses and their sources of sharia financing. This source of economic financing is not limited to the commercial finance, but also includes sharia social finance (zakat, infak/alms, waqf) as alternative financing in accordance with the principle of its use.

\section{Graph 1.1}

\section{Development of sharia financing}

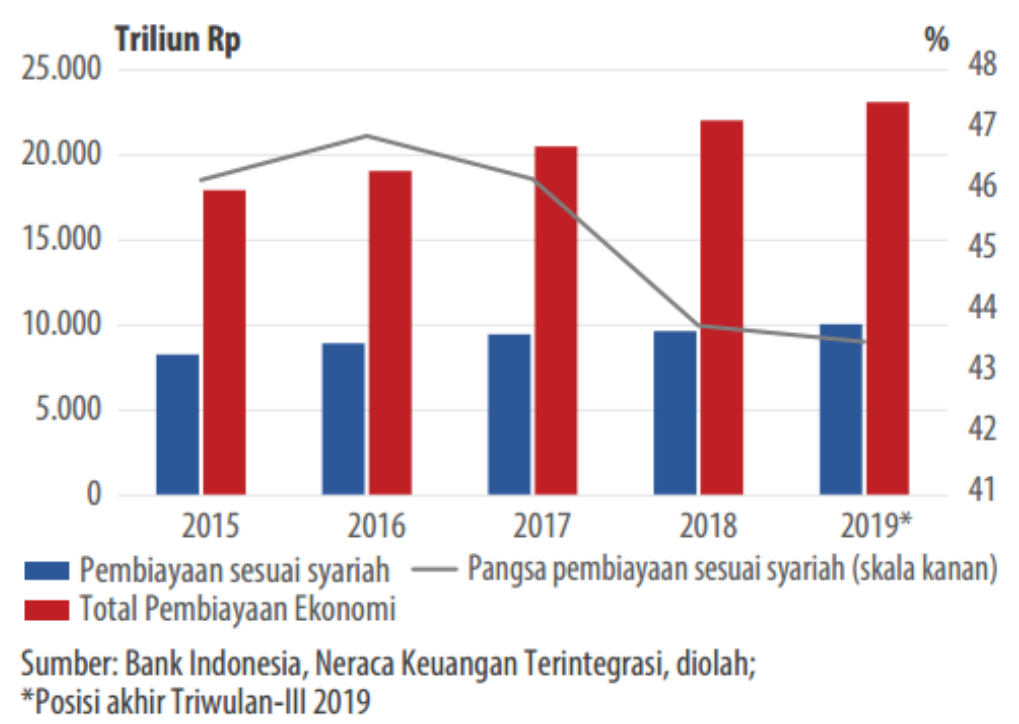

There are two types of financing contracts in Sharia banking when distinguished from the nature of returns on those contracts. This is where the terms NCC (Natural Certainty Contracts) and NUC (Natural Uncertainty Contracts) appear. Contracts included in the NCC are sales, leases, and wages. The contract included in the NUC is a revenue sharing agreement such as musyarakah, mudharabah, mukhabarah, musaqah, and muzara'ah (Hidayat, 2011).

Natural Certainty Contracts financing products at sharia banks offer a fixed and definite return that has been agreed between the seller (Bank) and the buyer (customer). The seller must inform the buyer of the acquisition price in advance and state the amount of profit added to the cost, in contrast to the credit system in conventional banks, whose return rate is 
not based on an agreement between the two parties but has been declared in the form of interest percentage.

NUC financing can be said to be a core product owned by Sharia banking that is not contained in conventional banking. However, behind the development of sharia banking which is growing in quantity, in its implementation, the amount of NUC type financing disbursed is smaller when compared to murabahah financing that belongs to the NCC type. As seen in the following financing table:

Table 1.1

Composition of financing in 2016 to 2019 (in percentage)

\begin{tabular}{|c|c|c|c|c|c|}
\hline \multicolumn{2}{|c|}{ Jenis Pembiayaan } & 2016 & 2017 & 2018 & 2019 \\
\hline \multirow{2}{*}{ NUC } & Mudharabah & $4,5 \%$ & $3,8 \%$ & $2,9 \%$ & $2,6 \%$ \\
\hline & Musyarakah & $30,4 \%$ & $32,7 \%$ & $33,9 \%$ & $37,5 \%$ \\
\hline \multicolumn{2}{|c|}{ Total NUC } & $34,9 \%$ & $36,5 \%$ & $36,8 \%$ & $40,1 \%$ \\
\hline \multirow{3}{*}{ NCC } & Murababah & $61,8 \%$ & $62,0 \%$ & $58,3 \%$ & $54,4 \%$ \\
\hline & Istishna & $\begin{array}{c}0,014 \\
\%\end{array}$ & $\begin{array}{c}0,010 \\
\%\end{array}$ & $\begin{array}{c}0,007 \\
\%\end{array}$ & $0,005 \%$ \\
\hline & Ijarah & $1,1 \%$ & $1,5 \%$ & $1,6 \%$ & $1,4 \%$ \\
\hline \multicolumn{2}{|c|}{ Total NCC } & $62,9 \%$ & $63,5 \%$ & $59,9 \%$ & $55,8 \%$ \\
\hline \multicolumn{2}{|c|}{ Qardh } & $2,2 \%$ & $0,0 \%$ & $3,4 \%$ & $4,1 \%$ \\
\hline \multicolumn{2}{|c|}{ Total Pembiayaan } & $100 \%$ & $100 \%$ & $100 \%$ & $100 \%$ \\
\hline
\end{tabular}

Source: OJK August 2020 (data processed)

The table above shows that every year the amount of financing disbursed by sharia banks always fluctuates in both NUC and NCC types of financing. However, the percentage of NCC financing is more dominating when compared to other types of financing, such as mudharabah, musyarakah, istishna', qardh and ijarah.

The rapid development of the economic situation today makes the company carry out various strategies to improve profitability to create a good sharia bank value as a reflection of the company's condition. According to Analisa (2011), the value of sharia banks can be influenced by the company's small profitability. Suppose the profitability of the company is good. In that case, the stakeholders consisting of creditors, suppliers, and investors will see the extent to which the company can generate profit from the company's sale and investment (Analisa \& Wahyudi, 2011; Samosir, 2017).

Based on the research results conducted by Raharjo (2019) on financing, the influence of murabahah and mudharabah has a significant impact on the value of companies with profitability as variable intervening. This shows that murabahah and mudharabah significant 
impact on profitability and profitability and profitability the value of Sharia Commercial Banks in Indonesia. The study results also show that murabahah and mudharabah affect the value of companies with profitability as intervening variables(Raharjo \& Wahyuni, 2019).

Dewi Research (2017) explains that profitability has a positive and significant effect on the value of sharia banks in the industrial sector of goods and consumption in the Indonesia Stock Exchange period 2012-2014(Dewi \& Sudiartha, 2017). Prayoga (2020) also explained that research on mudharabah transactions does not affect the value of Sharia banks, while musyarakah and qardh transactions have a positive effect on the value of Sharia banks. Zakat does not moderate the influence of mudharabah, musyarakah and qardh transactions on the value of sharia banks. Social performance variables moderate the influence of mudharabah, musyarakah and qardh transactions on the value of Sharia banks(Prayoga et al., 2020).

In Raharjo's research in determining the value of the company using the value of the company's shares by calculating the variable value of murabahah and mudharabah. Meanwhile, Dewi's research in measuring the value of companies that are projected with PER (Profit equalization reserve) is a portion of gross income on mudharabah income set aside before being divided into mudharib. Research from Prayoga measuring instruments used to explain the company's value by using FCF measurement (Free Cash Flow) is a measurement of performance growth and health of the company.

In the previous study, there were still many who discussed the company's value as measured by the overall revenue and stability of the company but did not explain if the value of the company is seen from the risk of financing. Researchers are interested in researching the value of companies by using NPF (Non Performing Financing) variables with NCC and NUC as gauges because it includes all financing (mudharabah, musyarakah, murabahah, istishna and ijarah). The researchers aim to explain the extent of the influence of the NCC and NUC on the NPF.

\section{REVIEW LITERATURE}

\section{Financing}

Financing broadly means financing or spending, i.e., funding spent to support planned investments, whether done own or run by others. In a narrow sense, financing is used to define funding conducted by financing institutions, such as sharia bank customers(Andrianto \& Firmansyah, 2019).

According to M. Syafi'i, Antonio explained that financing is one of the main tasks of the Bank, namely the provision of funds facilities and meeting the needs of the parties, which is a unit deficit(Andrianto \& Firmansyah, 2019). 
Types of Sharia Bank Financing, first is Natural Uncertainty Contracts (NUC). Natural Uncertainty Contracts (NUC) is a contract or business contract in which there is no certainty of payment either in quantity or time (Hidayat, 2011). In the NUC, the transacting parties mix their assets (both real assets and financial assets) into one entity and then bear the risk together to make a profit. Here, profits and losses are borne together. Therefore, this contract does not provide certainty of income (return), both in terms of amount and time (Karim, 2004).

This investment contract does not offer a fixed and definite return. It's a revenuesharing form. Revenue sharing is a form of return from investment contracts, which are included in natural uncertainty contracts (NUC). In general, the principle of revenue sharing in Sharia banking can be done in four contracts, namely: Al-Musyarakah, Al-Mudharabah, AlMuzara'ah, Al-Musaqah. But widely used in sharia banks are Al-Musyarakah and AlMudharabah (Antonio, 2001) in (Muhammad Lathief Ilhamy Nasution, 2018).

Second is Natural Certainty Contracts (NCC). According to Karim (Karim, 2004), Natural Certainty Contracts is a contract/contract in the business that provides certainty of payment, both in terms of the amount and time. This contract offers a fixed and definite return. The object of exchange (both goods and services) must also be determined at the beginning of the contract with certainty, quantity, quality, price, and delivery time.

Financing included in the NCC is a buying and selling (murabahah, salam, istishna') and rent (ijarah) and wages.

\section{Profitability}

The ultimate goal that a company wants to achieve is the most important profit or profit, in addition to other things. by obtaining maximum profit as targeted, the company can do much for the welfare of owners, employees, as well as improve the quality of products and increase new investments. A profit ratio or profitability ratio is also known as a rentability ratio to measure a company's profit level. A profitability ratio is a ratio to assess the company's ability to make a profit. This ratio also provides a measure of the effectiveness of a company's management. This is indicated by the profit generated from sales and investment income. The point is that the use of this ratio indicates the efficiency of the company (Kasmir, 2014).

\section{Value of sharia banks}

According to Harjito and Martono (2012) in Rafid (2017) revealed that there are three goals of the establishment of a company, the first to achieve maximum profit, the second prospers the owners of the company and the shareholders, and the latter is to maximize the value of the company. The value of a company can indicate the value of assets owned by a company, such as securities. Shares are wrong to make the value of sharia banks also high, 
and the share price is the price that occurs when stocks are traded on the market(Harjito \& Martono, 2012; Rafid et al., 2017).

It is a price willing to be paid by prospective buyers if the company is sold. The higher the value of sharia banks, the greater the prosperity that will be received by the owner of the company. The company's main objective is to maximize the value of sharia banks.

The results of Slamet Raharjo's research (Raharjo \& Wahyuni, 2019) show that murabahah and mudharabah have a significant effect on profitability, and mudharabah and profitability affect Sharia banks' value in Indonesia. The results of this study also showed that murabahah and mudharabah affect the value of sharia banks with profitability as intervening variables. This is according to Ade Dyah's research (2017), showing that together there is a significant influence between Mudharabah Financing, Musyarakah Financing, and Ijarah Lease Profitability Level. The increasing financing of Mudharabah, Musyarakah Financing, and Rent Ijarah, the higher the level of profitability (Dyah et al., 2017)

Dewi dan Sudiarta (2017) concluded that profitability had a positive and significant effect on the value of sharia banks in the industrial sector of goods and consumption in the Indonesia Stock Exchange period 2012-2014. The size of the company has a positive and insignificant effect on the value of sharia banks in the consumer goods industry sector on the Indonesia Stock Exchange for the period 2012-2014. Asset growth has a negative and insignificant effect on the value of sharia banks in the consumer goods industry sector on the Indonesia Stock Exchange for the period 2012-2014 (Dewi \& Sudiartha, 2017).

Cepi Juniar Prayoga (2020) The results of this study show that mudharabah transactions have no effect on the value of Sharia banks, while musyarakah and qardh transactions positively affect the value of Sharia banks. Zakat does not moderate the influence of mudharabah, musyarakah, and qardh transactions on the value of sharia banks. Social performance variables moderate the influence of mudharabah, musyarakah, and qardh transactions on Sharia banks' value (Prayoga et al., 2020).

\section{RESEARCH METHODS}

This type of research is correlational research. The approach of research conducted is a quantitative approach. The data used is secondary data in the form of the annual report obtained from the OJK website. The population that became the object of this study is Sharia Banks registered in BI as many as 11 Sharia banks during 2016-2019.

\section{Variable explanation}

\section{Value of sharia banks}

This study measured the value of Sharia bank companies using NPF. Non-Performing Financing (NPF) is one of the indicators in assessing the performance of Sharia banks. The high NPF level indicates the low performance of sharia banks due to many problematic 
financing. Yulianto and Solikhah, in wulandari (2020), stated that if a bank's NPF ratio increases, there will be a decrease in the number of deposits that can be collected from customers (Kuswahariani et al., 2020; Yulianto \& Solikhah, 2016).

The risk of financing distribution can be measured by the ratio of Non-Performing Financing (NPF). The NPF measures the Bank's ability to maintain the risk of defaulting on creditors' returns. The higher this ratio indicates that the Bank is unprofessional in its financing management (Riyadi, 2006). The level of health financing (NPF) contributes to the achievement of bank profits, so it can be concluded that the relationship between NPF and ROA is negative.

\section{Hypothesis Development}

Natural Uncertainty Contract financing is a contract that is done by not agreeing on the nominal profit to be received but agrees on the ratio of profit sharing received so that there is no certainty of nominal value to be received because it depends on the profit of the business. The results of Dian Anggraini's research (2019) show that NUC Financing has an insignificant effect on the profitability of Sharia Commercial Banks in Indonesia from October 2014 to March 2018 (Anggraini et al., 2019). This is relevant to the results of Muhammad Idris's research (2019), resulting in that the Variable Natural Uncertainty Contract (NUC) has a significant negative effect on profitability as measured by Return On Asset (Idris, 2019). Based on the description above, it can be formulated research hypothesis as follows:

H1: Natural Uncertainty Contract (NUC) affects profitability

NUC financing is a core product of Sharia banking that is not owned by conventional banks because it uses a revenue-sharing system. Renanda Rosita Wibowo (2019) partial composition of NCC financing insignificant to Return On Assets (ROA) at PT Bank Muamalat Indonesia for the period 2012-2016 (Wibowo \& Filianti, 2019). This is relevant to the results of Muhammad Idris's research (2019), resulting in that The Variable Natural Certainty Contract (NCC) has a significant positive effect on profitability as measured by Return On Asset (ROA) (Idris, 2019). it can be formulated research hypothesis as follows:

H2: Natural Certainty Contract (NCC) affects profitability

Profitability is the ability of the company to profit. The profit obtained by the company comes from the sale made by the company and investment policy by the company. Good profitability is demonstrated by the high profitability of the company. High profitability can be demonstrated by the company's good prospects so that investors will respond positively and the value of sharia banks will increase. The results of Dewa's research (2017) showed that profitability has a positive and significant effect on the Value of Sharia banks in Consumer Goods Industry Companies Registered in IDX for the period 2012-2014 
(Dewi \& Sudiartha, 2017). This is relevant to the research of Yana Setiana (2018) ROA has a positive and significant effect on the Value of Sharia banks Based on the description above (Setiana, 2018), it can be formulated research hypothesis as follows:

H3: Profitability Affects the value of sharia banks

Mudharabah and musyarakah are forms of funding decisions made by banking companies. Slamet and Salamah (2019) stated that the mudharabah decision had a significant effect on the value of Sharia banks of Sharia Commercial Banks. This result is caused by Mudharabah as a form of a funding decision made by banking companies (Raharjo \& Wahyuni, 2019). This is in line with the results of Cepi Junior's research (2020) stated that mudharabah transactions have no effect on the value of Sharia banks, while musyarakah and qardh transactions have a positive effect on the value of Sharia banks. Based on the description above (Prayoga et al., 2020), it can be formulated research hypothesis as follows:

H4: Natural Uncertainty Contract (NUC) affects the value of sharia banks

Murabahah is a contract for ordinary trading; The selling price consists of the purchase price plus a margin with a certain percentage, mark-up or cost-plus, as the seller's profit. This can be interpreted as murabahah is a form of funding to other parties. Increased funding through debt is one alternative to reducing agency costs. Debt can control managers to reduce perquisites, and company performance becomes more efficient so that the company's investor assessment will increase. Purnama Putra (2018) found evidence that Murabaha's funding decision, ijarah, positively affected the value of sharia banks. Based on the description above (Putra, 2018), it can be formulated research hypothesis as follows:

H5: Natural Certainty Contract (NCC) affects sharia bank value

Mudharabah and Musyarakah are cooperation between fund owners or investors with fund managers to conduct certain businesses with profit-sharing based on ratios. The results of Soenarto's research (2018) showed that mudharabah financing has a negative relationship to profitability. This is likely due to losses incurred from the business's run. Considering that any increase in financing in Sharia banks will increase the risk of financing because financing products are included in natural uncertainty contracts, the financing will bring uncertainty in generating profit or profit from the funds that the Bank has channeled to finance projects that have been agreed between the Bank and customers (Soenarto, 2018). The results of Astuti and Hotima's research (2016) showed profitability is able to be an intervening variable on the influence of liquidity on the capital structure (Astuti \& Hotima, 2016). Although Astuti and Hotima's research (2016) concept is different, the results show that profitability qualifies to be an intervening variable. Based on the description above, it can be formulated research hypothesis as follows: 
H6: Natural Uncertainty Contract (NUC) affects the value of sharia banks with profitability as variable intervening.

Murabahah according to Djamil (2012) is a trade at the base price plus known profit. The higher the problematic financing in the murabahah agreement will lower the level of profitability (Djamil, 2012). This is supported by research conducted by Slamet and Salamah (2019) murabahah financing has a significant effect on the value of Sharia banks of Sharia Commercial Banks with profitability as intervening variables (Raharjo \& Wahyuni, 2019). This is supported by research conducted by Fahrul, et al (2012) stated that the risk of murabahah financing affects the profitability of Sharia banks (Fahrul et al., 2012). The results of Andrian's research (2012) show that there is an influence of mediation so that profitability mediates the relationship between the capital structure and the value of sharia banks (Gamal, 2000). This indicates that profitability becomes a variable intervening relationship between the capital structure and the value of sharia banks, the research hypothesis can be formulated as follows:

H7: Natural Certainty Contract (NCC) affects the value of sharia banks with profitability as variable intervening.

Figure 1

\section{Frame of Mind}

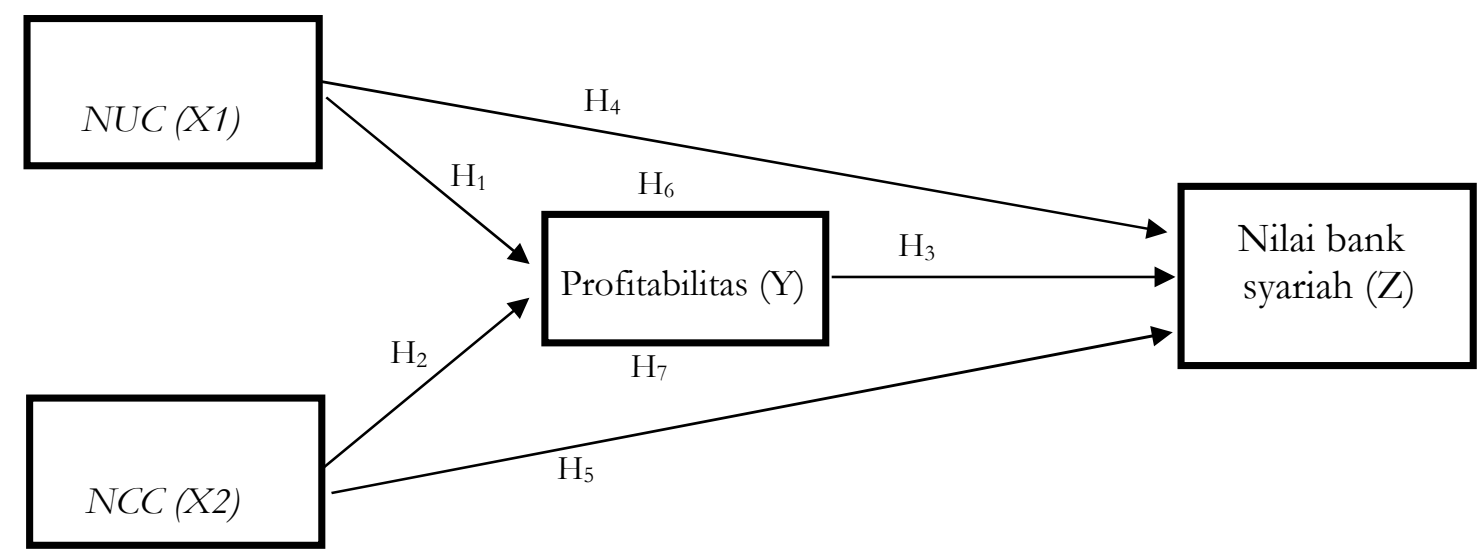

Figure 1 is a frame of mind that explains that the concept of sharia in the Islamic banking system is very detailed applied in the financing system because financing is very vulnerable to usury practices, so the form of sharia bank financing that is familiar to the public is murabahah and mudharabah financing. 


\section{ANALYSIS AND DISCUSSION}

The results of data analysis on the influence of NUC and NCC financing on sharia bank value of Sharia Commercial Banks in 2016-2019 with profitability as intervening variables obtained the following results:

Table 1

Path Analysis Phase I

\begin{tabular}{|ll|r|r|r|r|r|}
\hline \multirow{2}{*}{} & \multicolumn{2}{|c|}{$\begin{array}{c}\text { Unstandardized } \\
\text { Coefficients }\end{array}$} & $\begin{array}{c}\text { Standardized } \\
\text { Coefficients }\end{array}$ & \multicolumn{1}{c|}{$\mathrm{t}$} & Sig. \\
\cline { 3 - 8 } Model & \multicolumn{1}{|c|}{ B } & Std. Error & Beta & & \\
\hline 1 & (Constant) & -7101.349 & 1226.588 & & -5.790 & .000 \\
& NUC & .131 & .019 & .840 & 6.982 & .000 \\
\cline { 2 - 8 } & NCC & .011 & .018 & .074 & .613 & .543 \\
\hline
\end{tabular}

a. Dependent Variable: Profit

\begin{tabular}{|c|c|c|c|c|c|c|c|c|c|}
\hline \multirow[b]{3}{*}{ Model } & \multirow[b]{3}{*}{$\mathrm{R}$} & \multirow[b]{3}{*}{ R Square } & \multicolumn{5}{|c|}{ Model Summary } & & \\
\hline & & & \multirow{2}{*}{$\begin{array}{c}\text { Adjusted R } \\
\text { Square } \\
\end{array}$} & \multirow{2}{*}{$\begin{array}{c}\text { Std. Error of the } \\
\text { Estimate }\end{array}$} & \multicolumn{5}{|c|}{ Change Statistics } \\
\hline & & & & & R Square Change & F Change & df1 & $\mathrm{df} 2$ & Sig. F Change \\
\hline 1 & $.903^{\mathrm{a}}$ & .815 & .807 & 635.77432 & .815 & 99.424 & 2 & 45 & .000 \\
\hline
\end{tabular}

a. Predictors: (Constant), NCC, NUC

The model I Path Coefficient: Refers to the Model I Regression output in the Coefficients table section, it can be known that the significance values of both variables are $\mathrm{X} 1(\mathrm{NUC})=0.000$ and $\mathrm{X} 2(\mathrm{NCC})=0.543$ greater than 0.05 . This result concludes that The Regression of Model I, i.e., variable X1 (NUC), has a significant effect on Y (profitability), but X2 (NCC) has no effect on Y (Profitability). The amount of R2 or R Square value contained in the Model Summary table is 0.815 , and this indicates that the contribution or contribution of $\mathrm{X} 1$ and $\mathrm{X} 2$ influence to $\mathrm{Y}$ is $81.5 \%$, while the remaining $18.5 \%$ is a contribution from other variables not included in the study. Meanwhile, for e1 value can be searched with formula e1 $=\sqrt{ }(1-0.815)=0.185$.

Furthermore, in the path analysis phase, II will be analyzed the influence of murabahah and mudharabah on the value of sharia banks with profitability as intervening variables.

\section{Table 2}

\section{Path Analysis Phase II} coefficients $^{\text {a }}$

\begin{tabular}{|l|l|l|l|l|l|}
\hline & \multicolumn{2}{|l|}{$\begin{array}{l}\text { Unstandardized } \\
\text { Coefficients }\end{array}$} & $\begin{array}{l}\text { Standardized } \\
\text { Coefficients }\end{array}$ & $\mathrm{t}$ & Sig. \\
\hline Model & B & $\begin{array}{l}\text { Std. } \\
\text { Error }\end{array}$ & Beta & & \\
\hline
\end{tabular}




\begin{tabular}{|ll|l|l|l|l|l|}
\hline 1 & (Constant) & 7053.528 & 1480.717 & & 4.764 & .000 \\
& NUC & -.005 & .025 & -.055 & -.195 & .846 \\
\hline NCC & .026 & .017 & .301 & 1.538 & .131 \\
\hline Profit & -.503 & .136 & -.891 & -3.690 & .001 \\
\hline
\end{tabular}

a. Dependent Variable: NPF

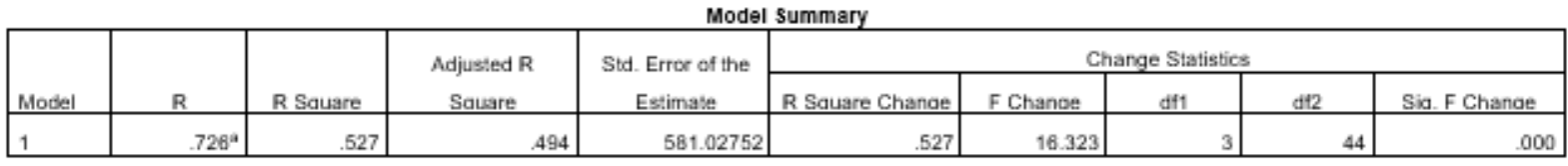

a. Predictors: (Constant), Profit, NCC, NUC

Model II Path Coefficient: Based on the Model II Regression output in the Coefficients table, it is known that the significance values of the three variables are $\mathrm{X} 1$ $(\mathrm{NUC})=0.131, \mathrm{X} 2(\mathrm{NCC})=0.845$, and $\mathrm{Y}=0.001$, only variable $\mathrm{Y}$ has a signification value smaller than 0.05. These results conclude that the Regression of Model II, i.e., variable X1, $\mathrm{X} 2$ has no influence on $\mathrm{Z}$ (sharia bank value), and $\mathrm{Y}$ has a significant effect on $\mathrm{Z}$ (sharia bank value). The magnitude of the $\mathrm{R} 2$ or $\mathrm{R}$ Square value contained in the Model Summary table is 0.527. This indicates that the contribution of $\mathrm{X} 1, \mathrm{X} 2$, and $\mathrm{Y}$ to $\mathrm{Z}$ is $52.7 \%$, while the remaining $47.3 \%$ is the contribution of other variables that are not studied. As for the value $\mathrm{e} 2=\sqrt{ }(1-0.527)=0.473$. Thus obtained the diagram of the path model structure II as follows:

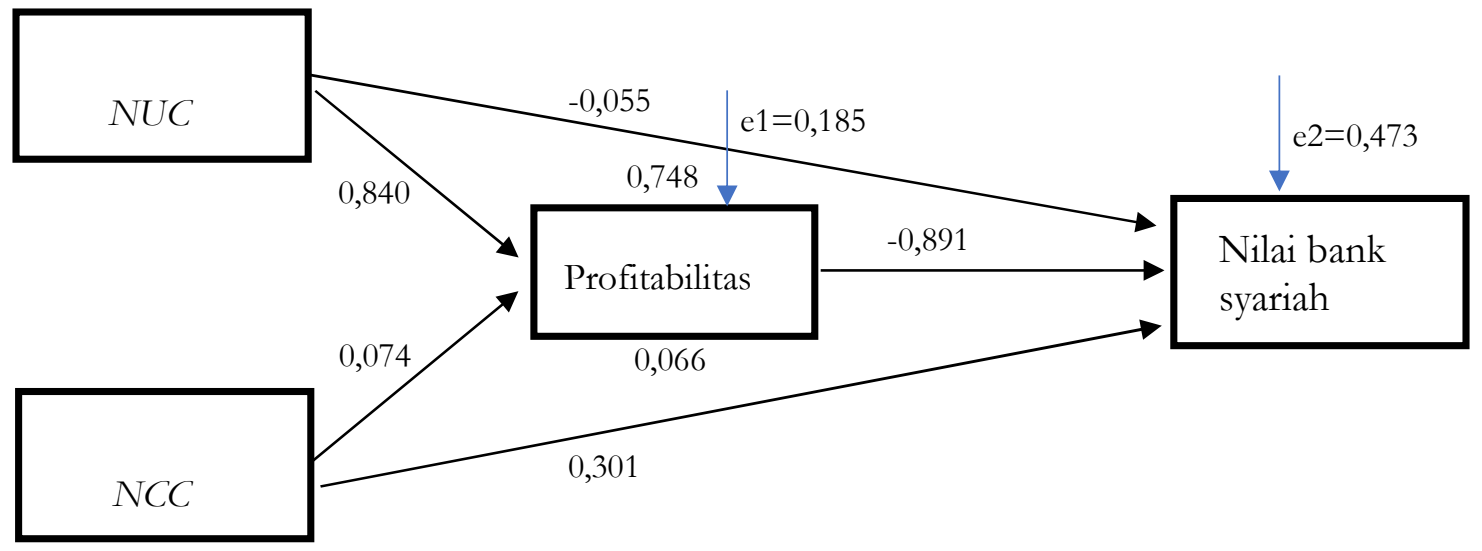

\section{Effect of Natural Uncertainty Contract (NUC) on Profitability}

The influence of NUC on profitability in Sharia Commercial Banks in 2016-2019 obtained the amount of t-hitung value $=6,982$ with $\mathrm{p}=0.000$. The calculation result shows that $\mathrm{p}<0.05$, so that $\mathrm{H} 1$ is accepted, meaning that nuc financing directly has a significant 
impact on the profitability of Sharia Commercial Banks. This is because the Bank's revenue in this NUC financing is in the form of profit-sharing with a mutually agreed ratio (portion) so that banks and customers can want profit-sharing in the form of revenue sharing. This study's results are inconsistent with the results of Dian Anggraini's research (2019), showing that NUC Financing has an insignificant effect on the profitability of Sharia Commercial Banks in Indonesia in the period October 2014 March 2018. The unsupported NUC variable on profitability is also irrelevant to the results of Muhammad Idris's research (2018), resulting in that the Variable Natural Uncertainty Contract (NUC) has a significant negative effect on profitability as measured by Return On Asset.

\section{Effect of Natural Certainty Contract (NCC) on Profitability}

The effect of NCC on profitability in Sharia Commercial Banks in 2016-2019 was obtained by the amount of $\mathrm{t}$-hitung $=0.613$ with $\mathrm{p}=0.543$. The calculation result shows that $\mathrm{p}>0.05$, so H2 is rejected, meaning that directly NCC financing has no significant effect on the profitability of Sharia Commercial Banks. This is because NCC is a sale and purchase of goods carried out by the seller by providing information to the buyer about the price of the product before the addition of profit that has been determined by the previous seller. The results of this study are consistent with the research of Renanda Rosita Wibowo (2019). The composition of NCC financing is partially insignificant to the Return On Assets (ROA) at PT Bank Muamalat Indonesia for the period 2012-2016. This is not relevant to the results of Muhammad Idris's research (2018), resulting in that The Variable Natural Certainty Contract (NCC) has a significant positive effect on profitability as measured by Return On Asset (ROA).

\section{Effect of Profitability on The Value of Sharia Banks}

The effect of profitability on the value of Sharia banks in Sharia Commercial Banks in 2016-2019 obtained the amount of t-hitung value $=-3,690$ with $\mathrm{p}=0.001$. The calculation result shows that $\mathrm{p}<0.05$, so that $\mathrm{H} 3$ is accepted, meaning that profitability has a significant effect on the value of Sharia banks of Sharia Commercial Banks. However, by looking at the regression coefficient (-0.503), this means that if the variable profitability rises by $1 \%$, then the value of sharia banks decreases by 0.503 , this indicates a negative relationship between profitability to the value of sharia banks (using NPF value), it is due to the profitability is the ability of the company to profit. The profit obtained by the company comes from the sale made by the company and investment policy by the company. Good profitability is demonstrated by the high profitability of the company. High profitability can be demonstrated by the company's good prospects so that investors will respond positively and the value of sharia banks will increase. The results of this study are supported by the results of Dewa's research (2017), showing that profitability has a positive and significant effect on 
the Value of Sharia banks in Consumer Goods Industry Companies Registered in IDX for the period 2012-2014.

\section{Effect of Natural Uncertainty Contract (NUC) on Sharia bank value}

The influence of NUC on sharia bank value in Sharia Commercial Banks in 20162019 obtained t-hitung value 0.195 with $\mathrm{p}=0.846$. The calculation result indicates that $\mathrm{p}>0.05$, so that $\mathrm{H} 4$ is rejected, meaning that indirectly NUC has no significant effect on the value of sharia banks of Sharia Commercial Banks. This result is due to NUC is a form of a funding decision made by banking companies. Optimal funding decisions will theoretically lead to increased prosperity/feasibility of shareholders. This study is relevant to research (2020) stated that mudharabah transactions have no effect on the value of Sharia banks, while musyarakah and qardh transactions have a positive effect on the value of sharia banks.

\section{Effect of Natural Certainty Contract (NCC) on Sharia Bank Value}

The effect of NCC on sharia bank value in Sharia Commercial Bank in 2016-2019 obtained thitung value $=1,538$ with $\mathrm{p}=0.131$. The calculation result indicates that $\mathrm{p}>0.05$, so H5 is rejected, means that indirectly NCC has no significant effect on the value of Sharia banks of Sharia Commercial Banks. This is because, in relation to banks, NCC transactions must be related to buying and selling activities. The Bank can buy the goods needed by its customers by paying cash to the seller. This research is inconsistent with Purnama Putra's research (2018), finding evidence that Murabaha funding decisions, ijarah, positively affect Sharia banks' value.

\section{Effect of Natural Uncertainty Contract (NUC) on Sharia Bank Value with Profitability as Intervening Variable}

Analysis of the Influence of NUC through Profitability on sharia bank value: it is known that the direct influence given by NUC on sharia bank value is -0.055 . While the indirect influence of NUC through profitability on sharia bank value is the multiplication between the beta value of NUC to profitability and the beta value of profitability to the value of sharia banks, namely: $0.840 \times(-0.891)=-0.748$. Therefore, the total influence given by NUC on sharia bank value is direct influence coupled with indirect influence, namely: -0.055 $+(-0.748)=-0.803$. Based on the above calculations, it is known that the value of direct influence is -0.055 and indirect influence is -0.803 , which means that the value of indirect influence is smaller than the value of direct influence. This result shows that indirectly NUC through profitability has a negative influence on the value of sharia banks.

From these results, H6 was rejected, meaning that NUC financing had no significant effect on the value of Sharia banks of Sharia Commercial Banks with profitability as intervening variables. Murabahah, according to Djamil (2012), is a trade at the base price plus known profit. The higher the problematic financing in the murabahah agreement, will lower the level 
of profitability. This is supported by research conducted by Fahrul et al. (2012) stated that the risk of murabahah financing affects the profitability of Sharia banks. The results of Andrian's research (2012) show that there is an influence of mediation so that profitability mediates the relationship between the capital structure and the value of sharia banks. This indicates that profitability becomes a variable intervening relationship between the capital structure and the value of sharia banks.

\section{Effect of Natural Certainty Contract (NCC) on Sharia Bank Value with Profitability as Intervening Variable}

Analysis of the Influence of NCC through Profitability on the value of sharia banks: it is known that the direct influence of NCC on the value of sharia banks is 0.301 . While the indirect influence of NCC through profitability on sharia bank value is the multiplication between the beta value of NCC to profitability and the beta value of profitability to the value of sharia banks, namely: $0.074 \times(-0.891)=-0.066$. Therefore, the total influence given by NCC on sharia bank value is direct influence coupled with indirect influence, namely: 0.301 $+(-0.066)=0.235$. Based on the above calculations, it is known that the value of direct influence is -0.055 and indirect influence is 0.235 , which means that the value of indirect influence is greater than the value of direct influence. This result shows that indirectly NCC through profitability has a significant influence on the value of sharia banks.

So that $\mathrm{H} 7$ is accepted, meaning that NCC financing has a significant effect on the value of sharia banks of Sharia Commercial Banks with profitability as intervening variables. This is because any increase in financing in Sharia banks will increase the risk of financing because the financing product is included in the natural uncertainty contracts, the financing will bring uncertainty in generating profit or profit from the funds that have been channeled by the Bank to finance the project that has been agreed between the Bank and the customer. The results of this study are supported by Astuti and Hotima's research (2016), showing profitability is able to be variable intervening on the influence of liquidity on the capital structure.

\section{CONCLUSION}

The application of Sharia-based banking activities is very detailed in its application, especially in financing products. This is because financing in banking is very easy to come into contact with usury practices so that forms of financing in Sharia banks that are well known to the public are grouped in Natural Uncertainty Contract (NUC) and Natural Certainty Contract (NCC). The results of this study show that nuc has a significant effect on profitability, but has no significant effect on the value of sharia banks. In contrast to the NCC results that have absolutely no significant effect on the profitability and value of sharia banks. This study also provides information that NUC has no effect on the value of sharia 
banks with profitability as variable intervening, in contrast to NCC, which affects the value of Sharia banks with profitability as variable intervening.

\section{Reference}

Analisa, Y., \& Wahyudi, S. (2011). pengarub ukuran perusahaan, leverage, profitabilitas dan kebijakan dividen terhadap nilai perusahaan (studi pada perusahaan manufaktur yang terdaftar di bursa efek indonesia tabun 2006-2008). Universitas Diponegoro.

Andrianto, \& Firmansyah, M. A. (2019). Buku manajemen bank syariah. In Cv. Penerbit Qiara Media (Issue September).

Anggraini, D., Mawardi, I., \& Financing, N. P. (2019). Analisis Faktor-Faktor Yang Mempengaruhi Profitabilitas Bank Umum Syariah Di Indonesia. Jurnal Ekonomi Syariah Teori Dan Terapan, 6(8), 1607-1619.

Antonio, M. S. (2001). Bank Syariah: dari teori ke praktik. Gema Insani.

Astuti, D. D., \& Hotima, C. (2016). Variabel Yang Mempengaruhi Struktur Modal Dengan Profitabilitas Sebagai Variabel Intervening (Studi Pada Industri Manufaktur Di Bursa Efek Indonesia). Dinamika Global: Rebranding Keunggulan Kompetitif Berbasis Kearifan Lokal, 398-411.

Dewi, D., \& Sudiartha, G. (2017). Pengaruh Profitabilitas, Ukuran Perusahaan, Dan Pertumbuhan Aset Terhadap Struktur Modal Dan Nilai Perusahaan. E-Jurnal Manajemen Universitas Udayana, 6(4), 242635.

Djamil, F. (2012). Penerapan Hukum Perjanjian dalam Transaksi di Lembaga Kenangan Syariah. Sinar Grafika.

Dyah, A., Martika, L. D., \& Rahmawati, T. (2017). Pengaruh Pembiayaan Mudharabah, Pembiayaan Musyarakah Dan Sewa Ijarah Terhadap Profitabilitas. Jurnal Riset Kenangan Dan Akuntansi (JRKA), 3(1), 53-68.

Fahrul, F., Arfan, M., \& Darwanis. (2012). Pengaruh Tingkat Risiko Pembiayaan Musyarakah Dan Pembiayaan Murabahah Terhadap Tingkat Profitabilitas Bank Syariah (Studi Pada Bank Aceh Syariah Cabang Banda Aceh). Jurnal Akuntansi Fakultas Ekonomi Unsyiah.

Gamal, S. (2000). Dasar-dasar Pariwisata. Penerbit Andi.

Harjito, A., \& Martono. (2012). Manajemen Keuangan (Kedua). Ekonisia.

Hidayat, T. (2011). Buku Pintar Investasi Syariah. Mediakita.

Idris, M. (2019). Pengaruh Pembiayaan Natural Uncertainty Contract (NUC), Natural Certainty Contract (NCC), Dan Non Performing Financing (NPF) Terhadap Profitabilitas Bank Umum Syariah Di Indonesia (Periode 2016-2018). UIN Raden Fatah.

Bunga (interest/fa'idah), (2004).

Karim, A. A. (2004). Bank Islam Analisis Fiqih dan keuangan (V). PT. RajaGrafindo Persada.

Kasmir. (2014). Analisis Laporan Keuangan. PT.Raja Grafindo Persada. 


\section{Vol 8 No 1: Januari 2021 15-30 \\ ISSN: 2460-9889 (Cetak) \\ ISSN: 2580-3565 (Online)}

https://journal.trunojoyo.ac.id/dinar/index

DOI: https://doi.org/10.21107/dinar.v8i1.10157

Kuswahariani, W., Siregar, H., \& Syarifuddin, F. (2020). Analisis Non Performing Financing (Npf) Secara Umum Dan Segmen Mikro Pada Tiga Bank Syariah Nasional Di Indonesia. Jurnal Aplikasi Bisnis Dan Manajemen, 6(1), 26-36. https://doi.org/10.17358/jabm.6.1.26

Muhammad Lathief Ilhamy Nasution. (2018). Manajemen Pembiayaan Bank Syariah. In FEBI UIN-SU Press. https://www.cairn.info/revue-informations-sociales-2005-3-page48.htm\%0Ahttp://repository.uinsu.ac.id/5050/1/Manajemen Pembiayaan Bank Syariah.pdf

Prayoga, C. J., Susilowati, D., \& Setyorini, C. T. (2020). Pengaruh Transaksi Mudharabah, Musyarakah Dan Qardh Terhadap Nilai Perusahaan Dengan Dimoderasi Zakat Dan $\begin{array}{lllll}\text { Kinerja Sosial. Jurnal Akuntansi Trisakti, } & 7(1), & 153 .\end{array}$ https://doi.org/10.25105/jat.v7i1.6145

Putra, P. (2018). Pengaruh Pembiayaan Mudharabah, Musyarakah, Murabahah, Dan Ijarah Terhadap Profitabilitas 4 Bank Umum Syariah Periode 2013-2016. Jurnal Organisasi Dan Manajemen, 14(2), 140-150. https://doi.org/10.33830/jom.v14i2.159.2018

Rafid, A. G., Pohan, H. T., \& Noor, I. N. (2017). Pengaruh Kinerja Keuangan Terhadap Nilai Perusahaan Dengan Pengungkapan Corporate Social Responsibility Sebagai Variabel Moderasi. Jurnal Akuntansi Trisakti, 4(2), 245-258.

Raharjo, S., \& Wahyuni, S. (2019). Analisis Pengaruh Pembiayaan Murabahah dan Mudharabah terhadap Nilai perusahaan dengan Profitabilitas sebagai Variabel Intervening. Jurnal Bisnis \& Manajemen, 19(1), 39-50.

Rivai, A. (2017). Risiko Pembiayaan Murabahah dan Musyarakah pada Profitabilitas Bank Umum Syariah. Al-Urban, 1(2), 189-197. https://doi.org/10.22236/alurban

Samosir, H. E. S. (2017). Pengaruh Profitabilitas Dan Kebijakan Utang Terhadap Nilai Perusahaan Yang Terdaftar Di Jakarta Islamic Index (JII). Journal Of Business Studies, 2(1), 75-83. http://journal.uta45jakarta.ac.id/index.php/jbsuta/article/view/787

Setiana, Y. (2018). Pengaruh Kinerja Keuangan Terhadap Nilai Perusahaan Study Kasus Pada Perbankan Syariah. In win Raden Fatah (Vol. 3, Issue 1). UIN Raden Fatah.

Soenarto, S. N. (2018). The Influence Of Murabahah, Mudharabah, Musyarakab Financing Towards Syariab Bank Profitability. Universitas Islam Indonesia.

Wibowo, R. R., \& Filianti, D. (2019). Pengaruh Komposisi Pembiayaan Non Bagi Hasil Dan Financing To Deposit Ratio (FDR)Terhadap Profitabilitas Pada PT Bank Muamalat Indonesia Tahun 2012-2016. Jurnal Ekonomi Syariah Teori Dan Terapan, 6(3), 477-488.

Yulianto, A., \& Solikhah, B. (2016). The Internal Factors of Indonesian Sharian Banking to Predict The Mudharabah Deposits. Review of Integrative Business \& Economic Research, 5(1), 210-218. 